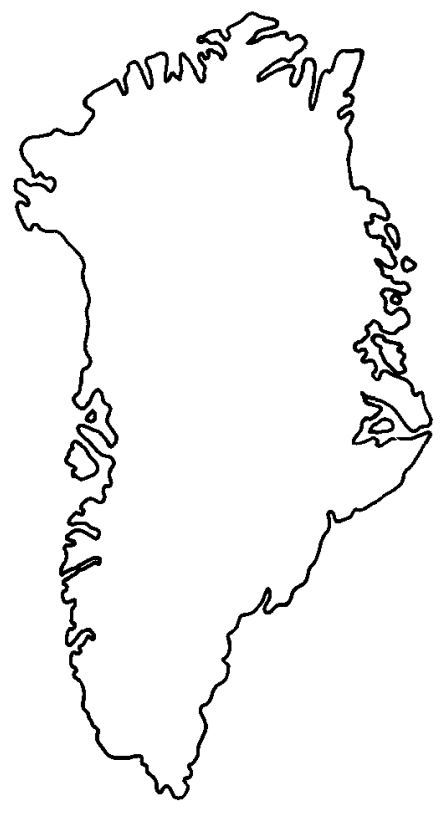

\title{
Firn temperature and meltwater refreezing in the lower accumulation area of the Greenland ice sheet, Pâkitsoq, West Greenland
}

\author{
Roger J. Braithwaite
}

\begin{abstract}
Firn temperatures and meltwater refreezing are studied in the lower accumulation area of the Greenland ice sheet as part of an international project on sea level changes. In the study area, 1440-1620 m a.s.1., meltwater penetrates several metres into the firn and refreezes, warming the firn by $5-7^{\circ} \mathrm{C}$ compared with annual air temperatures. This firn warming is closely related to surface melt which can be estimated by several methods. A relatively high degree-day factor is needed to account for the melt rates found.
\end{abstract}

R. J. B., Geological Survey of Greenland, Øster Voldgade 10, DK-1350 Copenhagen $K$, Denmark

GGU is studying meltwater refreezing in the lower accumulation area of the Greenland ice sheet as part of a project on sea level changes supported by the European Programme on Climatology and Natural Hazards (EPOCH). GGU's work under EPOCH is briefly described by Braithwaite et al. (1992) and Braithwaite \& Laternser (1993) while the present note describes temperature conditions in the field area which may be of more general interest.

\section{Background}

The field area is above Pâkitsoq, east of Ilulissat (Fig. 1), where GGU has measured mass-balance in the ablation area since 1982 (Thomsen et al., 1989).

A reconnaissance for the $\mathrm{EPOCH}$ project was made in August 1990 and field work was carried out in May and August of 1991 and 1992 respectively. The data only cover three years but temperature data from Ilulissat (formerly Jakobshavn) show that summer 1990 was relatively warm, summer 1991 was average and summer 1992 was very cold (Table 1). In contrast, annual mean temperatures were low in all three years. The field data must be interpreted against this background of longer term temperature variations.

Accumulation stakes for the EPOCH project extend from the 'Swiss Camp' at $1160 \mathrm{~m}$ a.s.1. to $1620 \mathrm{~m}$ a.s.l. well within the accumulation area. The surface features observed in August 1990 (Fig. 2) have hardly been seen since because of lower lying snow in both 1991 and 1992. Stake elevations and coordinates were measured with a hand-held receiver for the Global Positioning System (GPS). The runoff limit, i.e. highest elevation from which meltwater runs off to the ocean (Kasser, 1959), is between stakes 141 and 151 at about $1400 \mathrm{~m}$ a.s.l., and the summer melt from stakes 151 to 165 was of the order of $200 \mathrm{~kg} \mathrm{~m}^{-2}$ according to mass-balance measurements in summer 1991 (Braithwaite et al., 1992).

\section{Data collection}

Thermistor strings were steam-drilled to 10 metres depth at six out of the ten stakes for repeated measurements of firn temperature profiles (Table 2). The thermistor strings consist of six thermistors mounted onto a 7-conductor cable with a common conductor. Thermistor resistances were measured and converted to temperatures using the calibration curve provided by the manufacturer.

Thermistors were usually emplaced right at the end of field visits (May 1991, August 1991 and May 1992) with too little time to make enough measurements to estimate temperatures by the method of Humphrey (1991). This means that temperatures could usually be taken only during the next field visit. With hindsight, thermistor strings should have been installed right at the start of the project. 


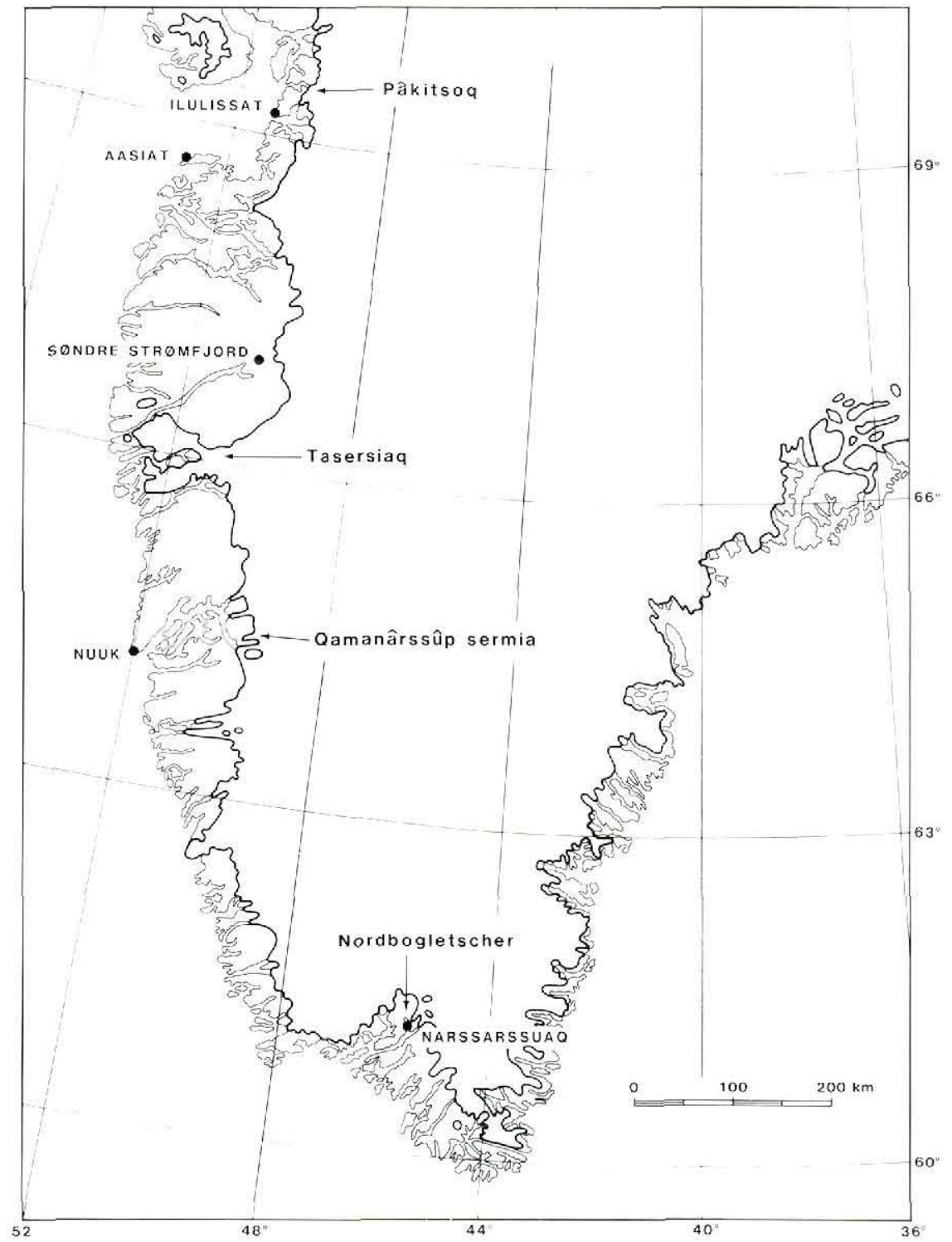

Fig. 1. Location map showing GGU's glacier-climate stations on the Greenland ice sheet, West Greenland. Dutch and Swiss stations were also operated east of Søndre Strømfjord and Ilulissat respectively.

\section{Firn temperatures}

Only two strings (stakes $157 \& 163$ ) were drilled early enough to be measured in August 1991 and they both show temperatures essentially at the melting point at depths of 1-2 metres, and much lower temperatures at 4

Table l. Mean temperature and departure from 30-year mean (brackets) for Ilulissat

(Jakobshavn), West Greenland. Units are ${ }^{\circ} \mathrm{C}$

\begin{tabular}{lrrr}
\hline & $1989 / 90$ & $1990 / 91$ & $1991 / 92$ \\
\hline Annual mean & $-5.7(-1.3)$ & $-5.8(-1.4)$ & $-6.4(-2.0)$ \\
Summer mean & $7.4(+0.8)$ & $6.6(0.0)$ & $5.2(-1.4)$ \\
\hline
\end{tabular}

metres and deeper. This shows that meltwater from the surface penetrated to a depth of between 2 and 4 metres during summer 1991, i.e. wetting more than a single year of accumulation such that the sites belong to the wet-snow zone of Benson (1959) and Muller (1962) as interpreted by Paterson (1981, fig. 2.1), or to the cold infiltration zone of Shumskii (1964, p. 410-420).

Temperatures in May 1992 at four strings (stakes 157. $161,163 \& 165$ ) have coldest temperatures near the surface and temperatures at any particular depth decrease with elevation.

In August 1992, temperatures were amazingly low in the surface 1-4 metres. If this had only been measured at one site, the data would have been rejected due to 'instrument error' but the same error cannot occur at 
Fig. 2. Overview of the GGU study area, showing stake locations, hydrological features and visible crevasses in the lower accumulation area, Pâkitsoq, as seen in August 1990.

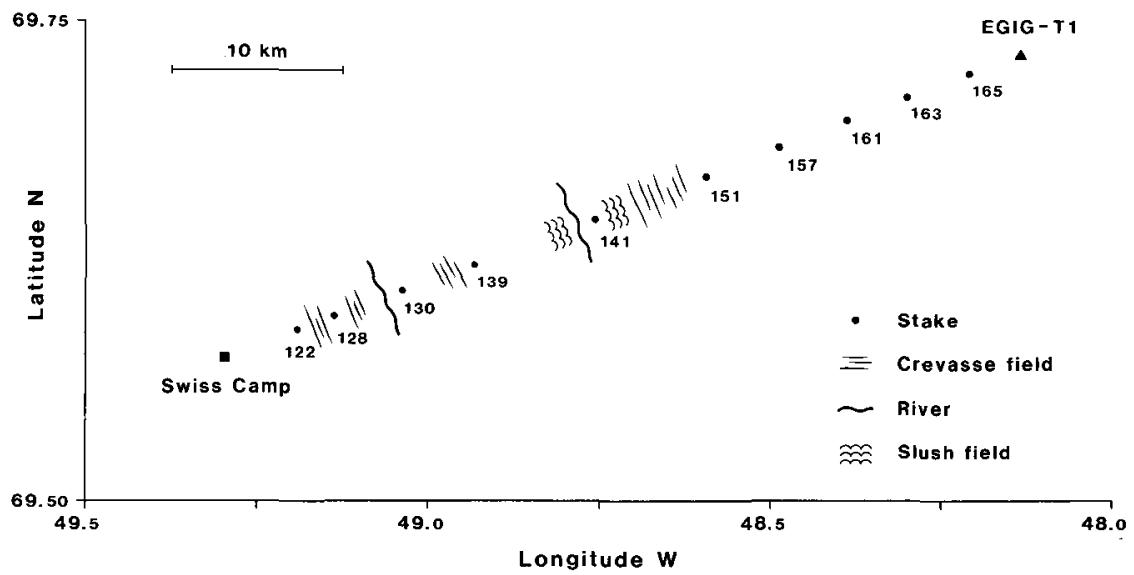

four sites. Presumably there was no deep penetration by meltwater on account of the very cold summer (see Table 1).

The temperature at 10 metres depth in firn is often taken as constant but the four sites all show slight variations, presumably a greatly attenuated seasonal variation. Temperature profiles should therefore have been taken to greater depth, e.g. 15 or 20 metres as suggested by Paterson (1981, p. 188).

In general, results show both colder 10 -metre temperatures and shallower meltwater penetration than expected at the start of the project.

\section{Meltwater penetration}

Meltwater percolates through firn at the melting point until it meets sub-freezing firn and then refreezes, warming up the firn by release of latent heat. Further meltwater fills up the pore spaces and percolates deeper into the firn when the residual water content is exceeded (Colbeck, 1976), or runs off if it meets an impermeable surface at the melting point. Firn temperature therefore strongly controls meltwater penetration.

The heat required to raise the temperature to the melting point is the cold content of the firn layer which, neglecting heat conduction, must be equal to the latent heat released by refreezing. Density and temperature profiles are both available to 10 metres depth at stakes 157 and 163 (Braithwaite \& Laternser, 1993) and the cold content of the firn can be estimated as a function of depth below the surface (Fig. 3) using a specific heat capacity of $2009 \mathrm{~J} \mathrm{~kg}^{-1}{ }^{\circ} \mathrm{C}^{-1}$. The melt required to reach any depth is obtained by dividing the cold content by the latent heat of fusion $\left(335 \mathrm{~kJ} \mathrm{~kg}^{-1}\right)$. The calculation is made for 1-metre firn layers and firn temperatures are interpolated as necessary between the depths at which they are measured. The relation between penetration depth and melt is almost linear, and a surface melt of about $100-220 \mathrm{~kg} \mathrm{~m}^{-2}$ could reach depths of $2-4$ metres as observed in summer 1991.

The above discussion applies to the maximum depth of meltwater penetration as some meltwater may be retained in pore spaces and only refrozen in the following winter. The amount of meltwater refrozen in this way is uncertain: Shumskii $(1964$, p. 288) states that it is negligible while Bazhev (1973) and Trabant \& Mayo (1985) says that it is significant.

\section{Firn warming}

On the highest parts of the ice sheet there is little or no melting at the surface and the firn temperature at 10-15 metres depth is close to annual mean air temperature (Loewe, 1970). At lower elevations, the difference between firn and air temperatures (firn warming) is related to the amounts of melt and accumulation

Table 2. Temperatures profiles in the lower accumulation area, Pâkitsoq. Units are ${ }^{\circ} \mathrm{C}$

\begin{tabular}{rrrrrrrrr}
\hline \multirow{2}{*}{ Stake } & Date & \multicolumn{1}{c}{$\mathrm{m}$} & \multicolumn{6}{c}{ Depth below surface - metres } \\
& & a.s.l. & 1 & 2 & 4 & 6 & 8 & 10 \\
\hline & & & & & & & \\
122 & $30 / 7 / 92$ & 1180 & $\mathrm{~m}$ & $\mathrm{~m}$ & -9.4 & -10.9 & -10.5 & -10.0 \\
151 & $1 / 8 / 92$ & 1440 & $\mathrm{~m}$ & $\mathrm{~m}$ & -8.5 & -9.7 & -9.3 & -9.0 \\
157 & $19 / 8 / 91$ & 1510 & -0.1 & -0.5 & -3.2 & -7.5 & -9.6 & -9.9 \\
& $14 / 5 / 92$ & & -14.7 & -13.8 & -11.8 & -9.8 & -9.1 & -9.0 \\
& $1 / 8 / 92$ & & -8.1 & -10.2 & -11.3 & -10.7 & -10.1 & -9.6 \\
161 & $15 / 5 / 92$ & 1530 & -15.6 & -14.7 & -13.8 & -11.7 & $\mathrm{~m}$ & -9.2 \\
& $2 / 8 / 92$ & & -7.0 & -9.4 & -11.4 & -11.2 & $\mathrm{~m}$ & -10.2 \\
163 & $19 / 8 / 91$ & 1620 & 0.0 & -0.1 & -4.0 & -9.7 & -12.4 & -12.8 \\
& $11 / 5 / 92$ & & -16.1 & -15.2 & -13.2 & -11.8 & -11.3 & -11.5 \\
& $2 / 8 / 92$ & & -10.7 & -12.3 & -13.0 & -12.8 & -12.2 & -12.1 \\
165 & $13 / 5 / 92$ & 1620 & -16.3 & -15.5 & -13.7 & -12.4 & -11.8 & -12.0 \\
& $2 / 8 / 92$ & & -10.9 & -12.5 & -13.5 & -13.2 & -12.7 & -12.5 \\
\hline & & & & & & & &
\end{tabular}




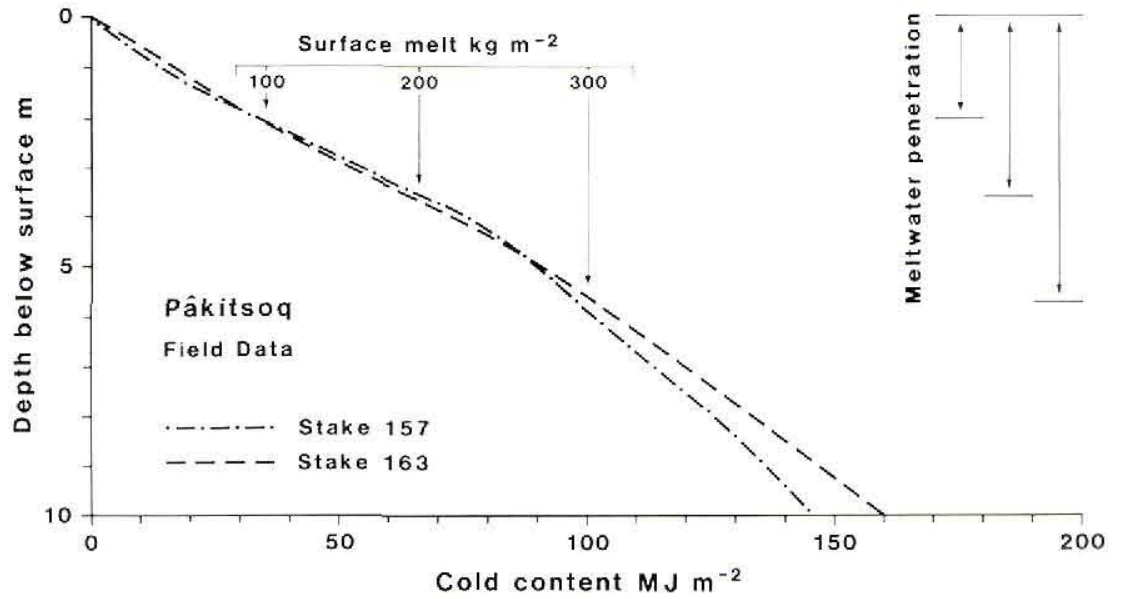

(Hooke et al., 1983). Reeh (1991) shows that the temperature difference increases linearly with increasing melt down to the runoff limit below which the temperature difference decreases again because latent heat is lost by runoff.

Annual mean temperatures $T_{\text {" }}$ at the stakes are estimated from long-term mean temperatures in Ilulissat using a temperature lapse rate of $-0.8^{\circ} \mathrm{C} / 100 \mathrm{~m}$ (Ohmura, 1987) and firn warming is given by $\Delta T=T_{1}-T_{a}$

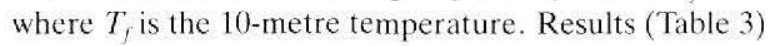
show that firn warming decreases with elevation.

The melt at stakes 151 to 165 is calculated from measured near-surface firn densities ( $0-5$ metres depth) by assuming that densification mainly occurs by formation of ice layers (Braithwaite et al., unpublished). Melt estimated in this way refers to a kind of average over the time taken to form the firn layer whose average density is used, e.g. about 5-10 years for 5 metres of firn.

Firn warming is strongly correlated with the surface melt (Fig. 4). A power law relation is used here as it seems reasonable that firn warming should be zero for zero melt but the precise shape of the relation should not be taken too seriously because the points are far from the origin. According to Braithwaite et al. (unpub-

Table 3. Firn warming at five stakes

\begin{tabular}{lcccccc} 
Stake & $\begin{array}{c}\text { Elev. } \\
\mathrm{m} \text { a.s.I. }\end{array}$ & $\begin{array}{c}\rho \\
\mathrm{kg} \mathrm{m}^{-3}\end{array}$ & $\begin{array}{c}M \\
\mathrm{~kg} \mathrm{~m}^{-2}\end{array}$ & $\begin{array}{c}T_{1} \\
{ }^{\circ} \mathrm{C}\end{array}$ & $\begin{array}{r}T_{a} \\
{ }^{\circ} \mathrm{C}\end{array}$ & $\begin{array}{c}\Delta T \\
{ }^{\circ} \mathrm{C}\end{array}$ \\
\hline 151 & 1440 & 707 & 282 & -9.0 & -15.6 & +6.6 \\
157 & 1510 & 676 & 267 & -9.5 & -16.2 & +6.7 \\
161 & 1530 & 645 & 251 & -9.7 & -16.3 & +6.6 \\
163 & 1620 & 624 & 239 & -12.1 & -17.0 & +4.9 \\
165 & 1620 & 593 & 221 & -12.3 & -17.0 & +4.7 \\
\hline
\end{tabular}

Fig. 3. Cold content versus depth below surface for two stakes in the lower accumulation area, Pâkitsoq. lished) runoff will occur with melt of more than about $350 \mathrm{~kg} \mathrm{~m}^{-2}$ so according to Reeh (1991) the curve in Fig. 4 should be inflected at higher melt values than those shown. This is supported by lower differences between ice and air temperatures at stake 122 , i.e. $+3.5^{\circ} \mathrm{C}$, and at the Swiss Camp, i.e. $+3.8^{\circ} \mathrm{C}$ (Greuell, 1992), where there is heat loss due to runoff.

Substitution of the present values of firn warming into the linear equation of Reeh (1991) gives very similar melt estimates to those found from the density-melt model, see Table 4 where melt estimates $M_{1}$ and $M_{2}$ refer to the density-melt and Reeh methods respectively. As each method involves much uncertainty, not least the correct choice of lapse rate, such close agreement is encouraging.

\section{Degree-day factor}

The degree-day factor relates melting during some period to the degree-day total, i.e. sum of positive temperatures, during the same period. It is certainly not a true constant and even for ice surfaces it varies from case to case (Braithwaite, 1992), while snow surfaces have much lower degree-day factors (Braithwaite \& Olesen, 1989). Degree-day factors (M/DDT) from the above melt estimates are given in Table 4 where degreeday totals $D D T$ are calculated from temperatures in Ilulissat using the same lapse rate as above and the method of Braithwaite (1985).

Degree-day factors are in good agreement for the two methods but are much larger than the value of $2.5 \mathrm{~kg}$ $\mathrm{m}^{2}$ per degree day given by Braithwaite \& Olesen (1989) for melting snow on Nordbogletscher. South Greenland (Fig. 1). Indeed the values here are comparable with degree-day factors for ice at the margin of the ice sheet. As degree-day factors for snow should be less 
Fig. 4. Estimated firn warming as a function of surface melt in the lower accumulation area, Pâkitsoq.

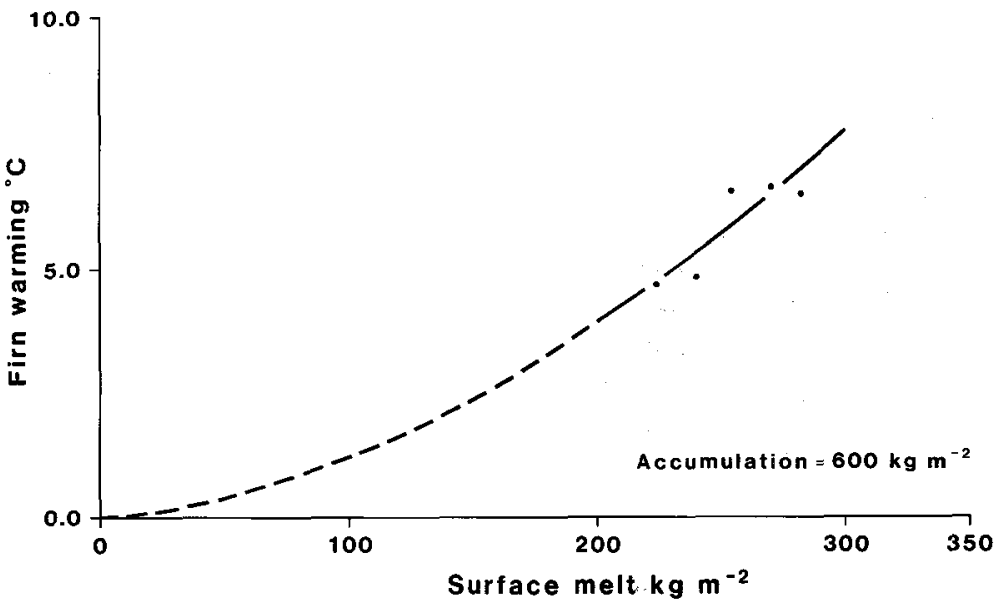

than those for ice under otherwise similar conditions, this suggests a relative increase in degree-day factor with elevation for both ice and snow, and such an increase has indeed been suggested by Van der Wal (1992, p. 27) for a profile east of Søndre Strømfjord (Fig. 1). High degree-day factors are also observed at Qamanârssûp sermia (Fig. 1) in winter (Braithwaite \& Olesen, in press). The reason is probably that high winds tend to occur with high temperatures which become increasingly rare at high elevations or in winter months such that the sensible heat flux is high in the few periods with melting.

\section{Effect of climate warming}

Higher air temperatures in winter will reduce winter cooling which would allow deeper penetration of meltwater in the following summer while higher air temperatures in summer will give more meltwater so the firn would be penetrated to greater depth. In either case there will be warmer firn, less refreezing, and greater

Table 4. Degree-day factors using melt estimates $M_{1}$ and $M_{2}$

\begin{tabular}{lcccccc} 
Stake & $\begin{array}{c}\text { Elev. } \\
\mathrm{m} \mathrm{a.s.l.}\end{array}$ & $\begin{array}{c}M_{1} \\
\mathrm{~kg} \mathrm{~m}^{-2}\end{array}$ & $\begin{array}{c}M_{2} \\
\mathrm{~kg} \mathrm{~m}^{-2}\end{array}$ & $\begin{array}{c}D D T \\
{ }^{\circ} \mathrm{C} d\end{array}$ & $\begin{array}{c}M_{l} / \\
D D T\end{array}$ & $\begin{array}{c}M_{2} \\
D D T\end{array}$ \\
\hline 151 & 1440 & 282 & 254 & 43 & 6.6 & 5.9 \\
157 & 1510 & 267 & 258 & 34 & 7.9 & 7.6 \\
161 & 1530 & 251 & 254 & 32 & 7.8 & 7.9 \\
163 & 1620 & 239 & 190 & 23 & 10.4 & 8.3 \\
165 & 1620 & 221 & 182 & 23 & 9.6 & 7.9 \\
& & & & & & \\
Mean & & & & & 8.5 & 7.5 \\
S.D. & & & & & \pm 1.5 & \pm 0.9 \\
\hline
\end{tabular}

runoff to the ocean with a consequent rise in sea level. However, it is impossible to forecast this in precise terms and a better physical understanding of meltwater movements in cold firn is still needed. This may involve collection of new field data but should be combined with better models to use existing data. Numerical models should be developed combining the hydraulics of meltwater movement with the thermodynamics of heat conduction and phase change. The models may take several man-years to develop but will be invaluable for model experiments on the effects of different climate scenarios and for identifying needs for new field data.

\section{Conclusions}

Melt rates are of the order of $100-300 \mathrm{~kg} \mathrm{~m}^{-2}$ at $1440-1620 \mathrm{~m}$ a.s.l. in the field area. Meltwater penetrates several metres into the firn and warms the firn by $5-7^{\circ} \mathrm{C}$ compared with annual air temperatures. Relatively high degree-day factors are needed to account for the estimated melt rates.

Acknowledgements. This study was supported by the European Community through contract EPOC-CT-0015 which is coordinated by Prof. D. Smith, Coventry University, U.K. The author thanks F. Kalsbeek, O. B. Olesen \& H. H. Thomsen (all of GGU), H. Blatter \& M. Laternser (both of Swiss Federal Institute of Technology, Zurich, Switzerland), S. Forsstedt (Unifly A/S), N. Humphrey (University of Wyoming, Laramie, USA), W. T. Pfeffer (University of Colorado, Boulder, USA), A. Russell (Kingston University, U.K.) and U. Stoller (Grønlandsfly A/S) for various help in carrying out the field work. 


\section{References}

Bazhev, A. B. 1973: Infiltration and run-off of melt water on glaciers. International Association of Scientific Hydrology Publication 95 (Symposium at Cambridge - Hydrology of Glaciers), 245-250.

Benson, C. S. 1959: Physical investigations on the snow and firn of Northwest Greenland 1952, 1953, and 1954. U.S. Army SIPRE Research Report 26, 70 pp.

Braithwaite, R. J. 1985: Calculation of degree-days for glacierclimate research. Z. Gletscherk. Glazialgeol. 20, 1-8.

Braithwaite, R. J. 1992: Degree-day factor, energy balance, and the increased melting of the Greenland ice sheet under a warmer climate. Rapp. Grønlands geol. Unders. 155, 79-83

Braithwaite, R. J. \& Laternser, M. 1993: Measurements of firn density in the lower accumulation area of the Greenland ice sheet: EPOCH 1992. Rapp. Grønlands geol. Unders. 159 (this report).

Braithwaite, R. J. \& Olesen, O. B. 1989: Calculation of glacier ablation from air temperature, West Greenland. In Oerlemans, J. (ed.) Glacier fluctuations and climatic change, 219233. Kluwer Academic Publishers.

Braithwaite, R. J. \& Olesen, O. B. in press: Seasonal variation of ice ablation at the margin of the Greenland ice sheets and its sensitivity to climate change, Qamanârssûp sermia, West Greenland. J. Glaciol.

Braithwaite, R. J., Pfeffer, W. T., Blatter, H. \& Humphrey, N. 1992: Meltwater refreezing in the accumulation area of the Greenland ice sheet: Pâkitsoq, summer 1991. Rapp. Grønlands geol. Unders. 155, 13-17.

Braithwaite, R. J., Laternser, M. \& Pfeffer, W. T. unpublished: Variations of near-surface firn density in the lower accumulation area of the Greenland ice sheet, Pâkitsoq, West Greenland. Manuscript submitted to $J$. Glaciol.

Colbeck, S. C. 1976: An analysis of water flow in dry snow. Water Resources Research 12(3), 523-527.

Greuell, W. 1992: Numerical modelling of the energy balance and the englacial temperature at the ETH camp, West Greenland. Zurcher Geogr. Schrift. 51, 81 pp.

Hooke, R. LeB., Gould, J. E. \& Brzozowski, J. 1983: Nearsurface temperatures near and below the equilibrium line on polar and subpolar glaciers. Z. Gletscherk. Glazialgeol. 19 (1), 1-25.

Humphrey, N. 1991: Estimating ice temperature from short records in thermally disturbed boreholes. J. Glaciol. 37 (127), 414-419.

Kasser, P. 1959: Der Einfluss von Gletscherrückgang und Gletschervorstoss auf den Wasserhaushalt. Wasser- und Energiewirtschaft 51(6), 155-168.

Loewe, F. 1970: Screen temperature and $10 \mathrm{~m}$ temperatures. $J$. Glaciol. 9(56), 263-268.

Müller, F. 1962: Zonation in the accumulation area of the glaciers of Axel Heiberg Island, N.W.T., Canada. J. Glaciol. 4(33), 302-310.

Ohmura, A. 1987: New temperature distribution maps for Greenland. Z. Gletscherk. Glazialgeol. 23(1), 1-45.

Paterson, W. S. B. 1981: The physics of glaciers, 380 pp. Oxford: Pergamon.

Reeh, N. 1991: Parameterization of melt rate and surface temperature on the Greenland ice sheet. Polarforschung 59(3), 113-128.

Shumskii, P. A. 1964: Principles of structural glaciology, 497 pp. (Translated from Russian by D. Kraus). New York: Dover Publications.

Thomsen, H. H., Olesen, O. B., Braithwaite, R. J. \& Weidick, A. 1989: Greenland ice-margin programme, a pilot study at Pâkitsoq, north-east of Jakobshavn, central West Greenland. Rapp. Grønlands geol. Unders. 145, 50-53.

Trabant, D. C. \& Mayo, L. R. 1985: Estimation and effects of internal accumulation on five glaciers in Alaska. Ann. Glaciol. 6, 113-117.

Wal, R. van der, 1992: Ice and climate. Ph.D. thesis, Rijksuniversiteit Utrecht, 144 pp. 